\title{
Syphilis in art: an entertainment in four parts. Part 2
}

\author{
R S Morton
}

The Sixteenth Century

Amico Aspertini (1475-1552), an unusual man by all accounts, painted "The Execution of St Valerianus" in 1506 (fig 13). It is an historical fact that three early Roman martyrs, Valerianus, Tiberitus and Maximus, were excecuted at one and the same time. The first two were brothers. Valerianus is said to have been the husband of St Cecilia ${ }^{14}$ and so, perhaps not surprisingly, this painting can be found in her shrine in Bologna. Note the figure on the right, so obviously emaciated and with bandaged legs. He carries a banner with the sign of Scorpio, which we have already met in Dürer's work for Ulsenius. It had long been known to dominate the genital sphere in humans. Thus, although Aspertini's painting is religiously based, it has harmonies and overtones in keeping with the still prevalent public pre-occupation with astrological data and dynamics, as determinants of personal fortune. ${ }^{11}$

How then should we interpret this work? We have a choice. Is the artist directing our attention to the new plague of syphilis or are we here concerned with the older plague of leprosy? My personal view is that the banner bearer is declaring himself a syphilitic and warning others that it too is associated with a kind of martyrdom and with death. Interpretation is far from easy and is an example of the early 16 th century cult of abstruse allusion approaching outright obscurantism. This point was taken up by the 19th Ecumenical, the so-called Council of Trent (in Northern Italy). It decreed in 1563 that religious paintings should be more direct and simple. Examples of educational zeal exceeding public receptivity are not unknown today.

The Renaissance did much to free artists from a pre-occupation with religious subjects. The laws of antiquity had forbidden artists to paint portraits of anyone who was not a prince or a wise or virtuous man. Now all that was changed. Even church frescos were abundantly adorned by commissioned portraits of recognisable individuals. Idealised images of common people satisfied their thirst for glory or immortality. ${ }^{15}$

Our next illustration may be an example of this.

Department of the History of Medicine, The University, Sheffield, UK

R S Morton
Figure 14 is entitled "La Belle Ferronière"-the ironmaster's wife. (The piece of jewellery encircling the sitter's head is also called a ferronière.) There have been claims that the model was a Princess of Mantua. Others believe the work to be a portrait of Lucrezia Crivelli, mistress of Lodovico Sforza the Duke of Milan who welcomed the army of Charles VIII of France to his city state on 22nd February 1495 after a brief and bloodless siege. It is believed by many that the plague which attacked Charles' undisciplined army was the morbus gallicus. It spread like wildfire throughout Europe, when his demobilised mercenaries returned to their own countries.

There is certainly a striking resemblance between "La Belle Ferronière" and Leonardo da Vinci's portrait of Lucrezia Crivelli ${ }^{15}$ and it is little wonder that our portrait was at one time attributed to da Vinci. Today the concensus opinion in the art world is that "La Belle Ferronière" should be ascribed to Antonio Giovani Boltraffio (1467-1516), a Milanese pupil of da Vinci. The work is thought to have been completed about 1515 . It hangs in the Louvre. ${ }^{16}$ The subject is certainly attractive. Note how delightfully haughty and yet how placid she is. Is this simply the drama of the idealised; or has the artist represented the sitter's self image and yet found some inner nobility, what Christian teaching called "the good within"? Such thoughts may be considered to contrast with the story that surrounded this picture when it was first hung. ${ }^{17}$ Modern authorities have dismissed the story as a fiction but each reader will judge personally whether or not it has the ring of truth.

Francis I of France became King in 1515 at the age of twenty-one. Like many despotic monarchs of his time, he had many mistresses. The motto of his court was that royal blood did not defile and many cuckolded noblemen took no exception to royal favours being shown to their wives. The burghers, however, were faithful to a more rigid code of conduct and were less ready to accept the royal droit de seigneur. Such a one was the husband of La Belle Ferronière.

The story tells us that Francis I, riding in his carriage, saw the beautiful lady at the doorway of her husband's work-shop. Next day a courtier called and persuaded her that the Queen would welcome an opportunity to make her acquaintance. Such a request could hardly be refused and so the 


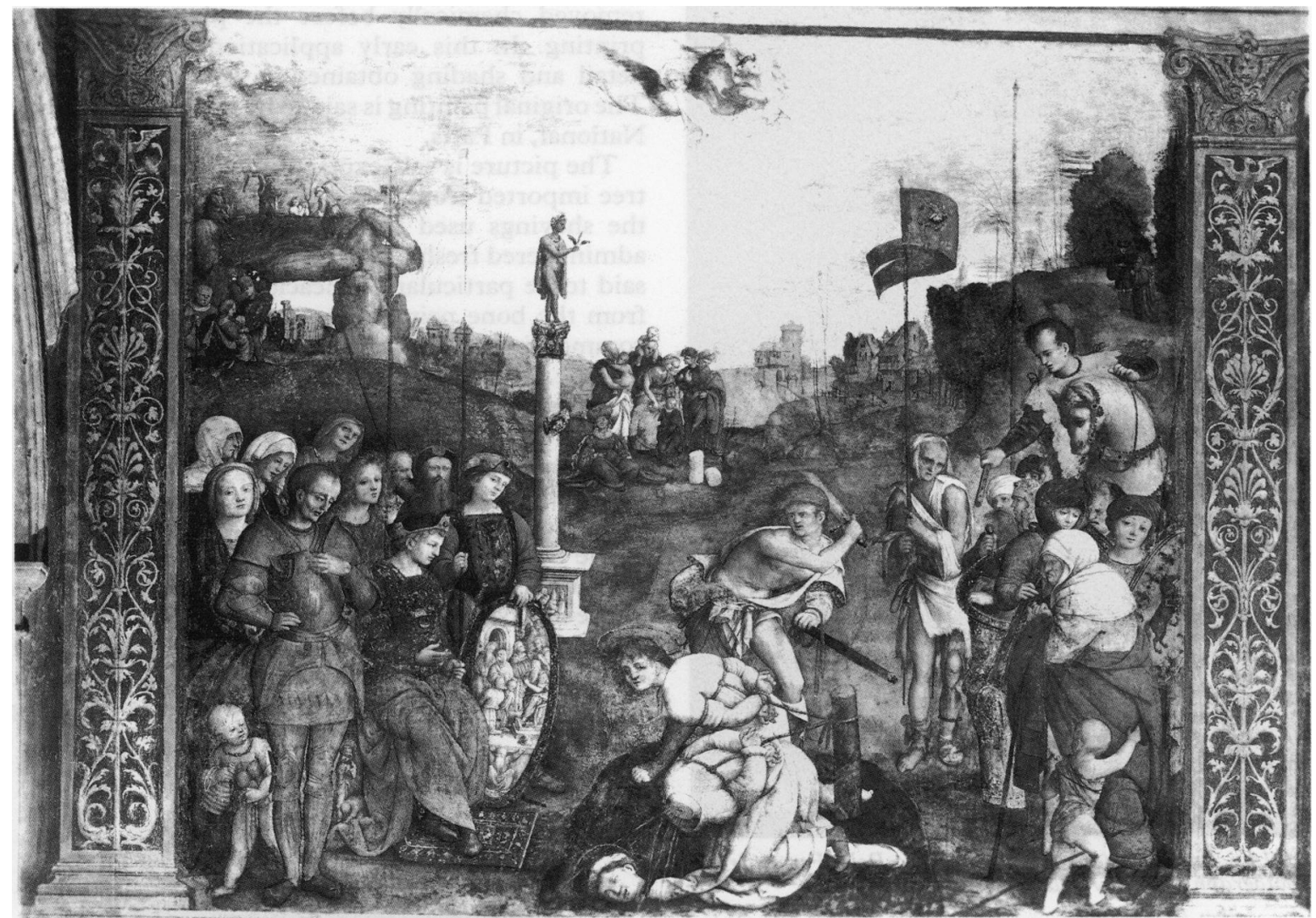

Fig 13 Amico Aspertini. Decapitation of St. Valorianus and his brother. Mural, Church of St. Cecilia, Bologna. Courtesy Convento des Giacomo, Maggiore, Bologna.

inevitability we associate with real tragedy commenced. The carriage which called next day took her not to the Queen's apartments but to one of the King's hide-outs in the Bois de Boulogne. And so the affair began. The husband did not for long accept the story of the Queen's desire for frequent visits. Distrait, he roamed the streets of Paris. Although upright, just and highly moral, his torment resolved itself into a lust for vengeance. A chance encounter with une fille de nuit determined for him the course he should follow. He sought and bought love where he could find it. This remorseless pursuit acquired for him his weapon of revenge and so the syphilis which killed the King at 53, reached him through "La Belle Ferronière".

The provenance or pedigree of Hans Holbein the Younger's 1523 "Portrait of a Leper (so-called)" is well established (fig 15). It is the sitter's diagnosis which is in question. A Boston dermatologist believes the boy's condition to be impetigo contagiosa. Panofsky, the art historian, is in no doubt that the diagnosis is secondary syphilis. ${ }^{18}$ The sensitive and tragic face of the boy is portrayed with merciless realism in black ink and red and yellow chalk. The nature and distribution of the lesions-papular and absent from the corners of the mouth and the junction of ear pinna to face-makes impetigo unlikely. Panofsky's diagnosis of syphilis can also be questioned. He placed much emphasis on a pencilled inscription on the back of the drawing which was erased between 1876 and $1910 .{ }^{19}$ The alleged inscription read "Portrait of Ulrich van Hutten in the year of his death". Ulrich van Hutten was a well known German poet, humanist, patriot and religious reformer. He had by his own account several attacks of syphilis and wrote denouncing most harshly the value of mercury treatment. There may have been more than one reason for his vehemence; his family, like the infamous Fuggers, had an interest in "making a corner" of the imports of guaiacum, the popular therapeutic alternative to mercury, from the West Indies. Ulrich van Hutten did in fact die in the year noted at the head of the drawing, 1523. It is known that he was small of stature and puny but even allowing for artistic licence, this portrait does not suggest a man of 35 years, which was van Hutten's age in the year of 


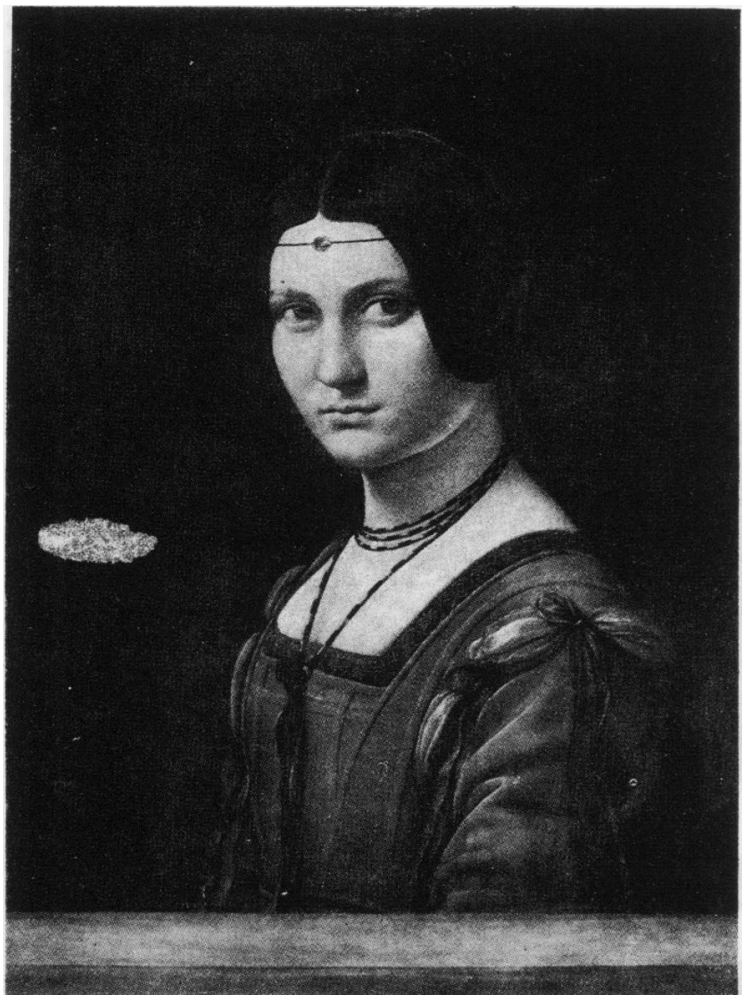

Fig 14 Antonio Giovani Boltraffio. La Belle Ferronière. Photograph of a copy in author's possession.

his death. Nor do known woodcut portraits of van Hutten-I have inspected three-resemble this boy. ${ }^{20}$

What of the lesions themselves? Many are nodular rather than papular and their size and random distribution do not fit well with secondary syphilis as we know it. The lack of any pattern in the arrangement of the nodules would tend to preclude late nodular syphilis, even one brought on prematurely by inadequate treatment. No-one seems to have considered a non-venereal treponematosis. ${ }^{1} \mathrm{~A}$ diagnosis of tuberculoid leprosy cannot be excluded. When you next view the original in the Fogg Art Museum in Cambridge, Massachusetts, USA, please send me a postcard with your considered opinion.

Mention of guaiacum prompts the inclusion of an engraving by Jan van der Stradenus, of a painting by Joan Galle (1570-1626) executed late in the 16th century (fig 16). Engraving is a generic term used to cover several methods of multiplying prints. Sometimes the artist and engraver are one and the same, but not in this case. The type of engraving used in this case is called intaglio. The necessary lines and etchings were made on a copper plate by the application of acid, where the covering of resin had been etched by a sharp metal stylo. The remaining resin is removed chemically before the plate is used for printing. In this early application of intaglio the detail and shading obtained is quite remarkable. ${ }^{21}$ The original painting is said to be in the Bibliotheque National, in Paris.

The picture is self-explanatory. The lignum vitae tree imported from the West Indies is stripped and the shavings used to make a concoction which is administered fresh to the patient as guaiacum. It was said to be particularly efficacious in those suffering from the bone pains of the morbus gallicus and so common in the first hundred years of the disease in Europe. According to my researches guaicum has not appeared in a pharmacopoeia since 1677 and then as a gum.

Our next is a 17th century engraving by Jacques Laniet of an anonymous 16th century etching in the Paris National Library (fig 17). It concerns the flight of the Spanish from Naples when it was retaken by the Duke of Guise late in the 16th century. It shows a figure in a barrel being treated with mercury, vaporised from warming pans. This is the method of treatment commonly alluded to as "fumigation". The etching is simply called "A Spaniard sweating

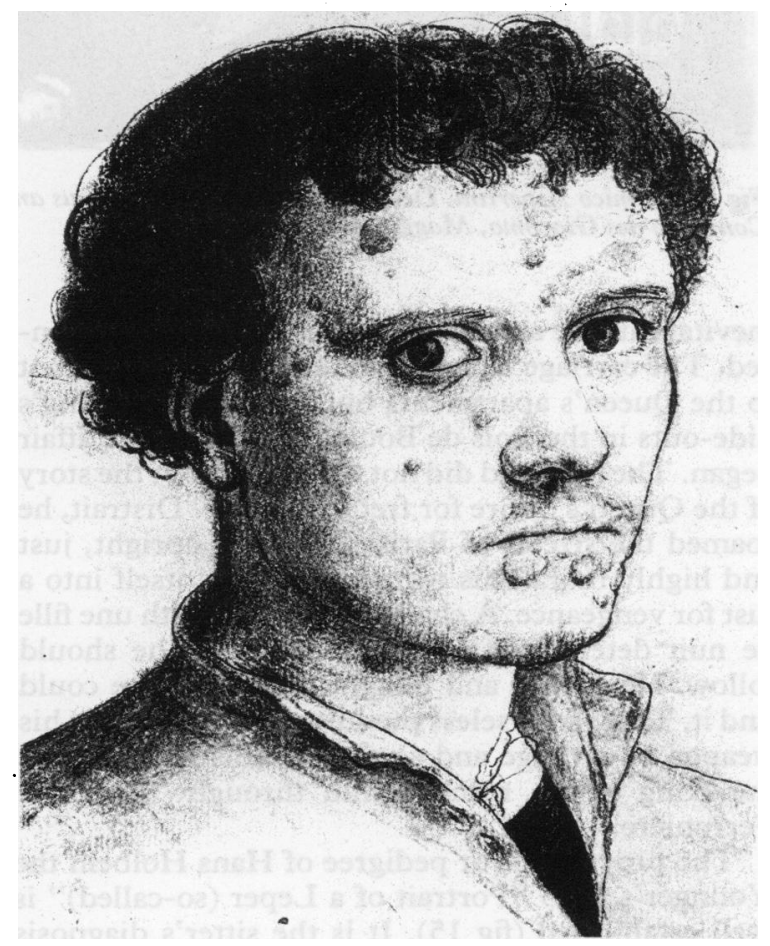

Fig 15 Hans Holbein the Younger. Head of a Young Man, 1523; black and coloured chalks, black ink and yellow and grey wash, $205 \times 152 \mathrm{~mm}$. Courtesy of Fogg Art Museum, Harvard University, Cambridge, Massachusetts. Gift of Paul J. Sachs, Class of 1900. "A Testimonial to my friend Felix M. Warburg'. 


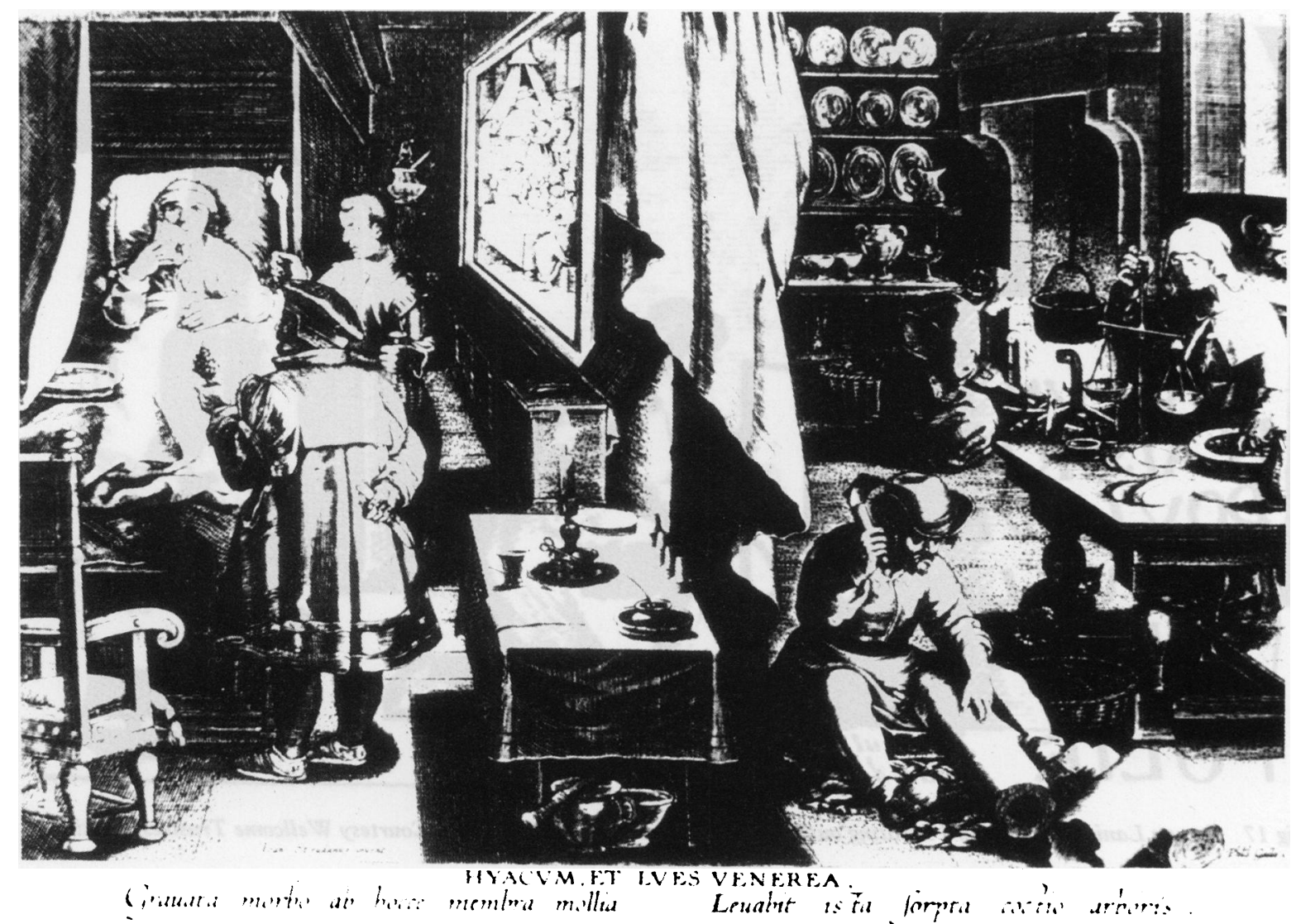

Fig 16 Philip Galle. Engraving after Jan van der Straet (Stradanus). One plate from the set Nova Reperta, Antwerp. c. 1600. Courtesy Wellcome Trustees, London.

out his pocks." 2223 The barrel is inscribed "For one pleasure a thousand pains". Medical students in my time preferred a freer translation-"For one night with Venus, a lifetime with Mercury".

The role of armies in the spread of syphilis is well illustrated in fig 18, variously titled "The Baggage", "Impedimenta" and "Le Triomphe". It shows camp followers with Venus. This 1539 wood engraving also appeared later in the 16th century, in Rouen, under the title "Wagon of Love". The satirically stated, moral purpose of the picture is clear; Venus's chariot is pulled by goats. ${ }^{2324}$

This potential of Venus to reveal associations with sex and syphilis was followed up. Many artists' representations of Venus were viewed in the hope of finding some significant symbolism so popular in the 16 th century.

We have already seen roses associated with Venus (fig 5). They are generally seen as her flowers. Have flowers some special significance? Festal crowns of roses were worn by Roman Emperors and those who crucified "the King of the Jews" parodied this by giving him a crown of thorns. Since then, in artistic symbolism, thorns have implied grief and tribulation. St Catherine of Sienna, for example, has thorns as the sign of her martyrdom. Furthermore, of all plants and flowers, the thorn has become the one most closely associated with sin. That ancient Jewish sect, the Pharisees, who now personify self-righteous hypocrisy, wore thorns in the hems of their gaberdines (those long upper garments), to remind themselves to guard against sinning and to give us the concept of mortification of the flesh in the phrase "thorn in the flesh".

Thorns in the flesh have been found in two 16th century works portraying Venus. Bronzino (150372) was an allegorical painter. In his masterpiece, "Allegory of Venus and Cupid" (fig 19), several allegories may be discerned; for example, regarding time (Chronus, top right), regarding cheating (note the masks) and retribution (the girl in green with the scorpion's tail). But the title appears to direct our attention to the intertwined bodies of Venus and Cupid. Is there, as some have suggested, "some 


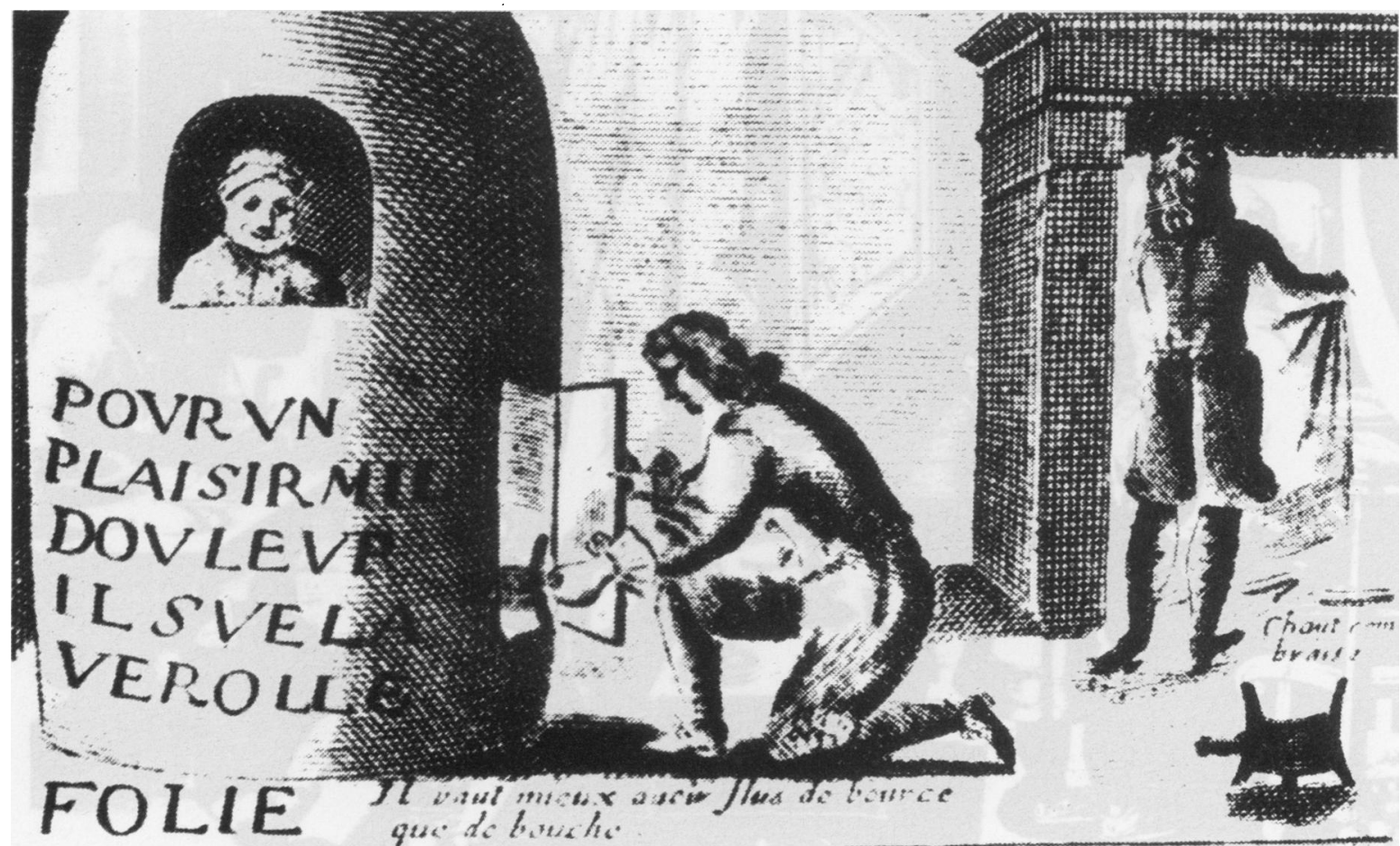

Fig 17 Jaques Laniet. A Spaniard sweating out his pocks. Engraving, Paris c. 1660. Courtesy Wellcome Trustees, London.

\section{LE BAGAGE}

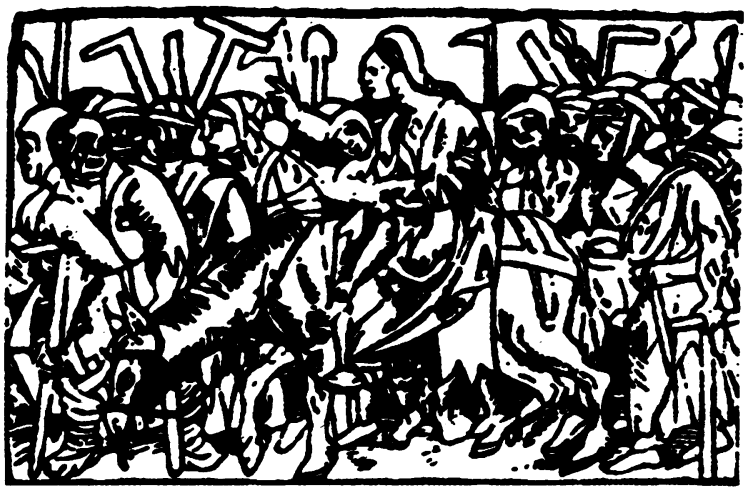

Fig 18 Le Bagage i.e. The Impedimenta (of the army). Triumph of the high and mighty Dame Syphilis, Queen of the Fountain of Love (Le Triomphe de treshaute et puissante Dame Verolle). Lyons, 1539 (Anon). Courtesy of the Bodleian Library, Oxford (Douce M 169).

Fig 19 Angelo Bronzino. An Allegory, (formerly called, Venus, Folly, Cupid and Time). $146 \times 116 \mathrm{~cm}$. c. 1546. Courtesy Trustees of the National Gallery, London.

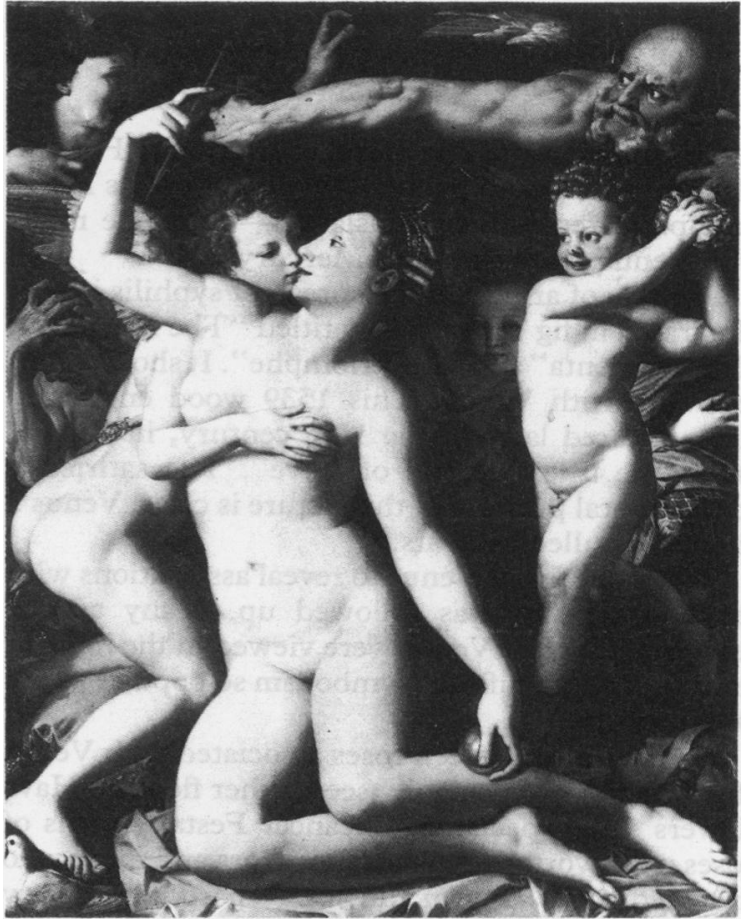




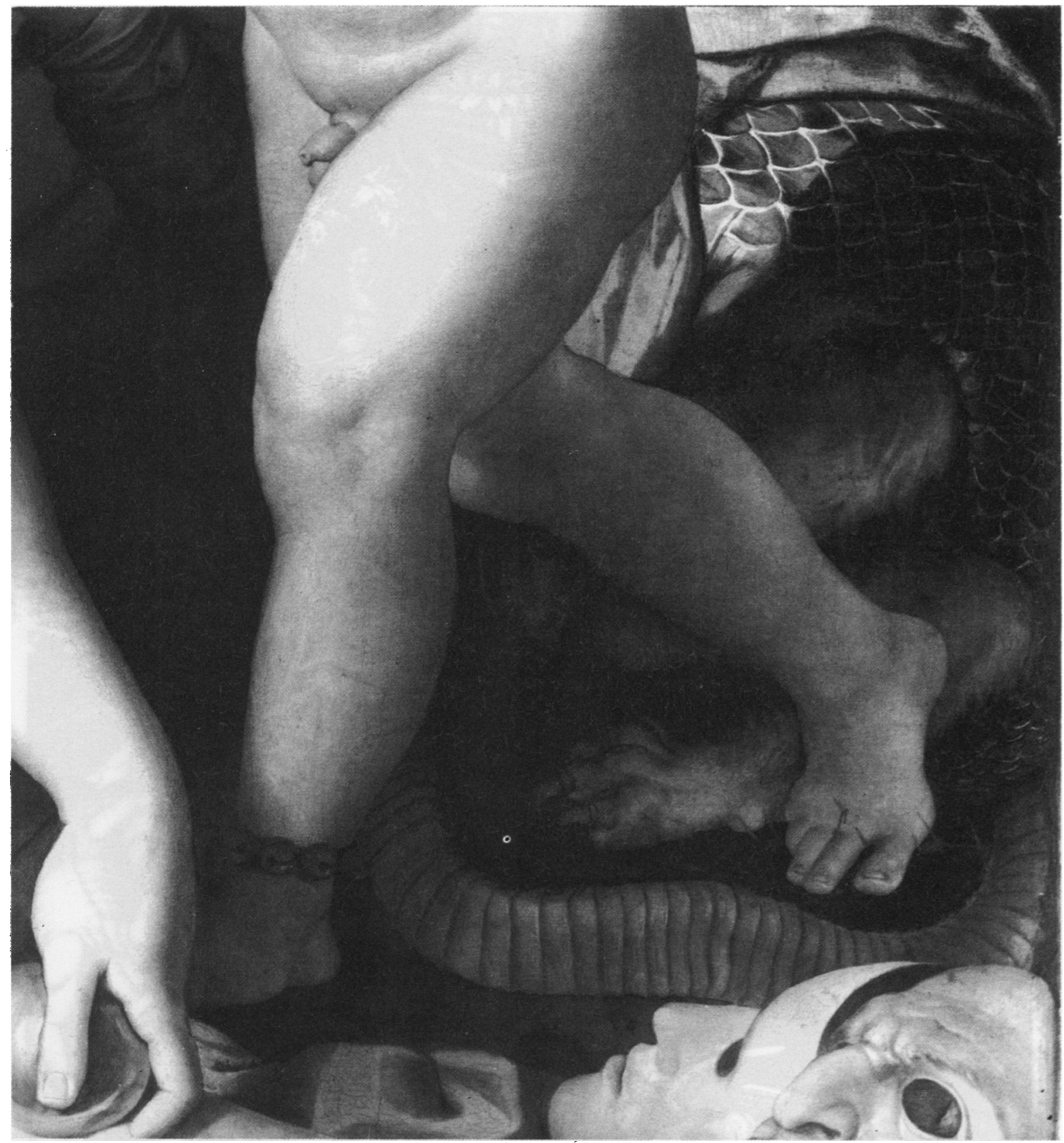

Fig 20 Detail of Fig. 19. Courtesy Trustees of the National Gallery, London.

elusive obscenity"? We can certainly see human sexual love, that is, erotic experience, transposed in statuesque fashion. It is in fact just the opposite of the moral declaration it first appears to be. The significance of the thom piercing the right foot of the boy holding the roses (fig 20), like that of the whole picture, is not entirely clear. ${ }^{25}{ }^{26}$ It may be a symbolic warning to the flower-bearing symbolic suitor that sex is not without hazard.
Giorgio Ghisi (1520-82) was born and died in Mantua, capital of one of the rich duchies of Italy's northern plain. His metiers were damascene work and engraving. ${ }^{27}$ One engraving shows Venus hiding in a rose bush. Her blood from a thorn prick colours the roses. But it is Giorgio Ghisi's engraving, "Venus and Adonis", after a painting by his brother Teodoro, which forms fig 21 . Venus seems more enthusiastic than the beautiful boy, Adonis, with his 


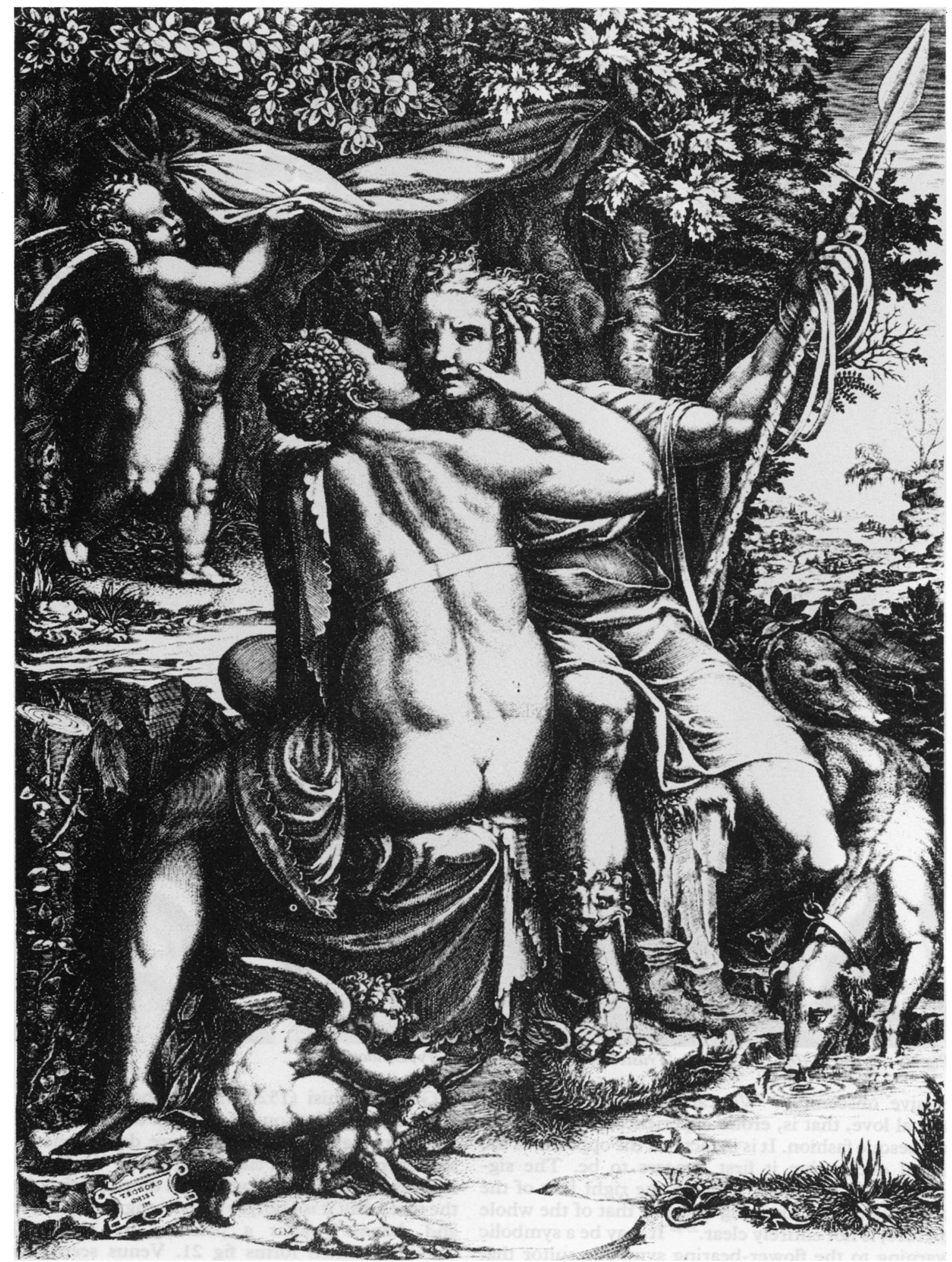

Fig 21 Giorgio Ghisi. Venus and Adonis. Engraving after Teodoro Ghisi. c. 1555. Courtesy of Courtauld Institute of Art, London. 
boar-hunting spear. The Ghisis appear to see the pair as Shakespeare did in his "Venus and Adonis":

"Rose cheeked Adonis bled him to the chase.

Hunting he loved: but love he laughed to scorn.

Sick-thoughted Venus makes amain unto him

And, like a bold-faced suitor'gins to woo him."

Behind the couple are two distinct examples of leaves. On our left we have a black-thorn leaf, the one usually associated with spines and thorns and producing white flowers and sloes. The other leaf is much more like the thorn-apple, long a common weed of waste places in southern Europe and presumably familiar to the Mantua-dwelling Ghisis. All parts of this plant are poisonous. They contain hyoscine, atropine and stramonium. Perhaps the Ghisis purposely deployed both thorn-bearing plants to give the clearest possible warning of the hazards ahead for those succumbing to a libidinous Venus.

The role of Venus in the story does not end with the Ghisis. Indeed we are to learn just why syphilis was so rightly called a venereal disease. In postMedician Florence the art and the humanism which had been such outstanding features of the Renais- sance, began to fade. Both were no longer regarded as civic virtues. Sensitivity in the form of good manners, reliance and restraint, matched by dress sense and good deportment, took their place. These characteristics, together with learning, became the mark of a gentleman. With this cult of individualism the broad basis of art narrowed. The poseur grew in stature as he affected appreciation of art, rather than its practice and patronage. He became the measure of European society's slow decay. Of course the heroic Florentine traditions of dedication, civic pride and individual responsibility for one's destiny remained strong enough for long enough to keep a much diminished number of Italian artists in action; and even to maintain them as a focus for the whole continent for many years. Our next artist is a product of this period.

Otto van Veen (1556-1629) was both a painter and a scholar. He spent much of his youth studying in Florence; and in Rome too, before returning to his native Netherlands, a worthy product of the Renaissance. His interests in classical history and literature are essentially the clue to an interpretation of his "Image of Indiscreet Youth", executed in 1595 (fig

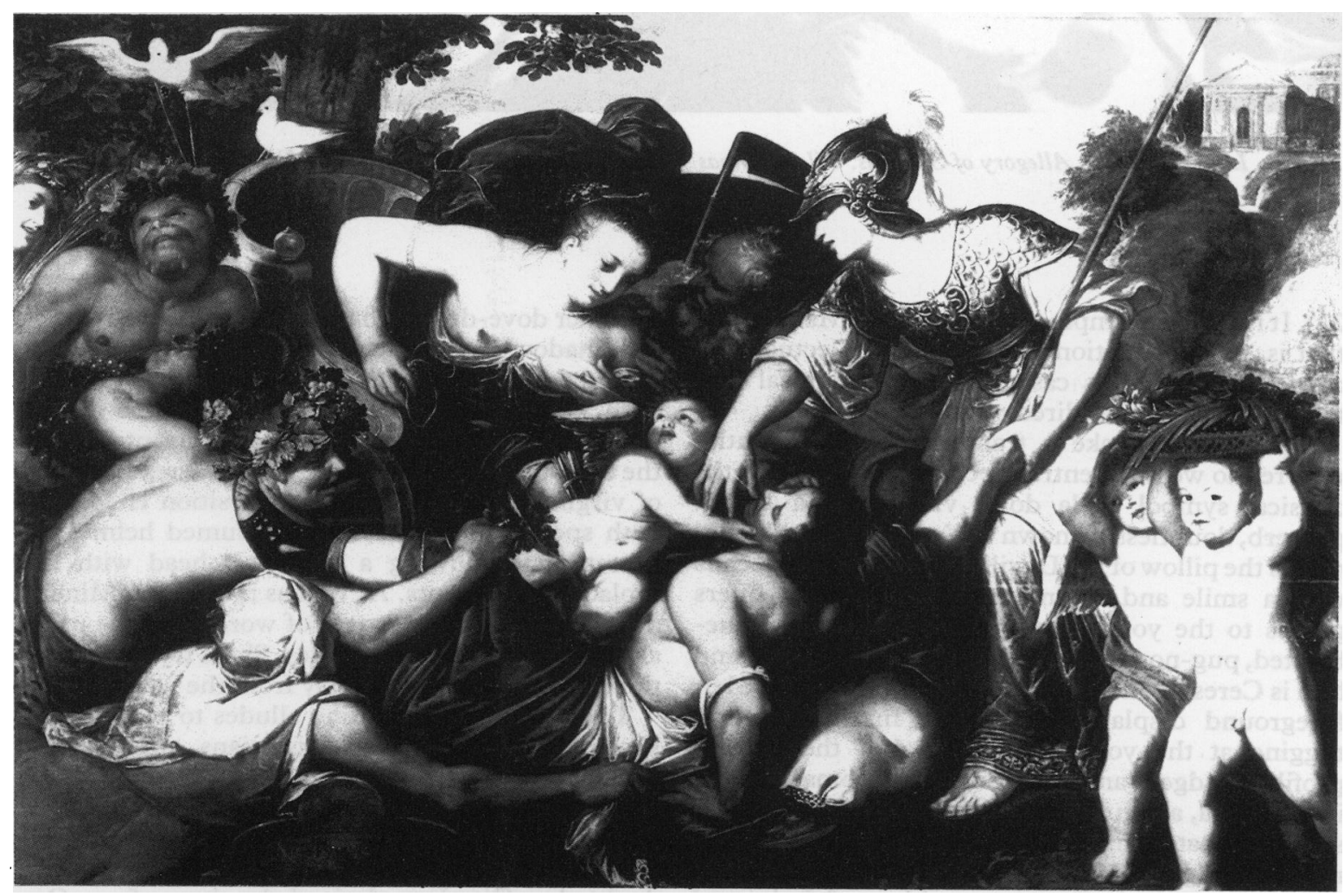

Fig 22 Otto van Veen. Image of Indiscreet Youth. Oil on canvas. 1595. Courtesy National Museum, Stockholm. 


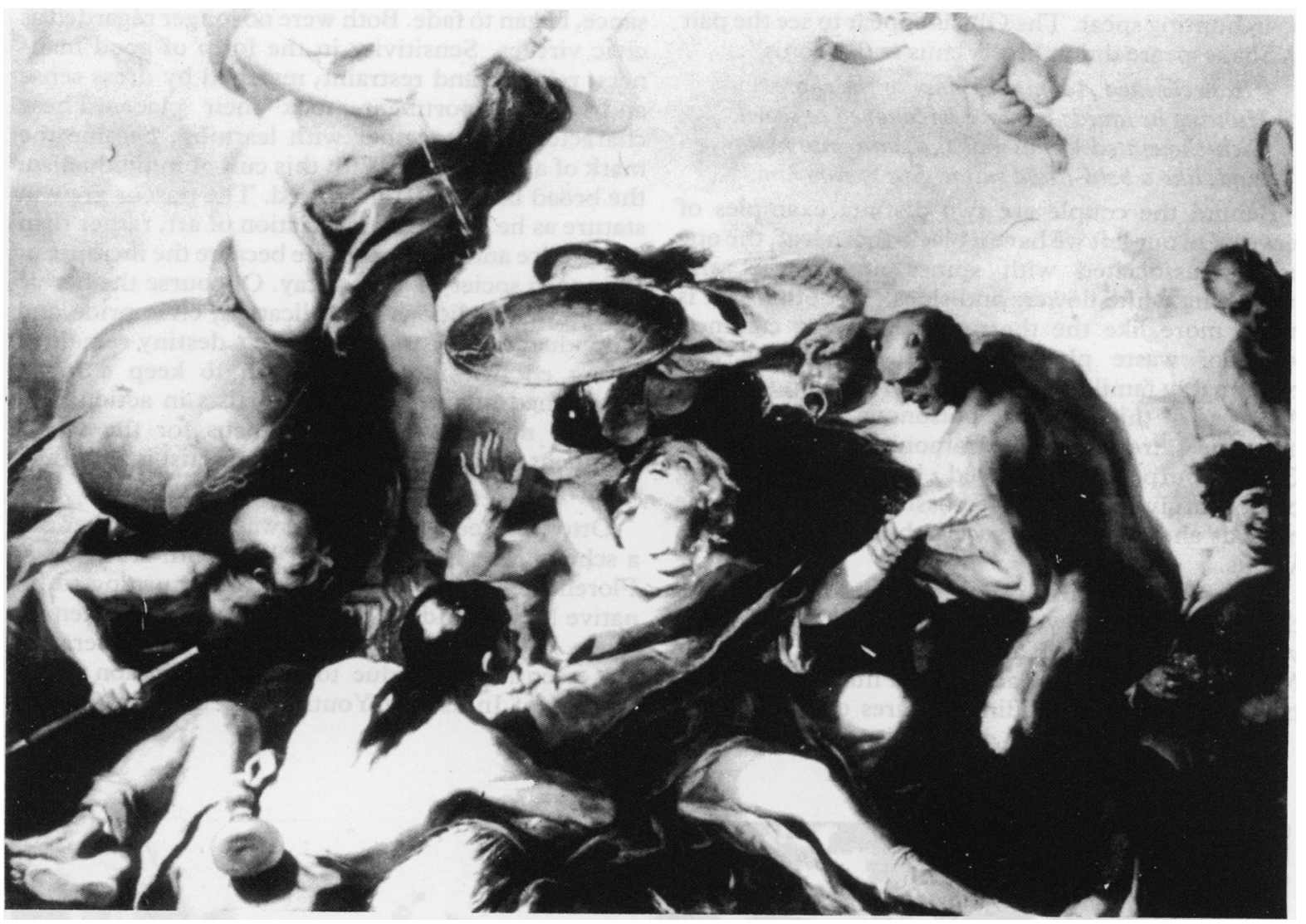

Fig 23 Luca Giordono. Allegory of Syphilis. Oil on canvas. Courtesy Städelsches Kunstinstitut, Frankfurt.

22). It is a good example of what is called Mannerism, that is, its appreciation is based on intellectual preoccupations-in this case with myothological fantasy-rather than on direct visual perception.

So we must make a translation. The "youth" referred to we find central, reclining on a pillow, the classical symbol of la dolce vita. An old Dutch proverb, doubtlessly known to Van Veen, says "Idleness is the pillow of the Devil". Centre left is Bacchus with a smile and an inviting gesture as he offers grapes to the youth. Behind Bacchus is his winebloated, pug-nosed step-father, Selenius; and behind him is Ceres, Goddess of the Harvest. The figure left foreground displays a muscular male right arm tugging at the youth's clothing, but the figure's profile, headgear and dress suggest a woman. Could it be Libera, a regular consort of Bacchus? Pickering suggests that it might be Vertumnus, the Roman mythology god of the seasons, in the disguise he assumed to seduce Pomona, goddess of fruits and fruit-trees, before marrying her. ${ }^{28}$ Centrally is Venus with her dove-drawn chariot. She holds the reins. In her shadow is Chronus with a mindful restraining hand on her shoulder. The milk motif in association with Venus signifies serious contamination in classically based paintings. Cupid takes an interest and the two putti or cherubs share a laurel wreath, symbol of virginity. In a commanding position is Minerva with spear and resplendent in plumed helmet and breast plate showing a Medusa's head with hair replaced by serpents. As well as much else, Minerva in mythology is protectress of workers in the useful and ornamental arts and trades. She is trying to direct the contaminating milk away from the youth.

That van Veen's painting alludes to syphilis only became apparent to art historians after seventy years, ${ }^{18}$ that is, in 1664 when Luca Giordano (16321705) produced his "Allegory of Syphilis" (fig 23). The Staedelsches Kunstinsitut at Frankfurt has recently restored this painting. There seems little doubt that Giordano derived the theme from Otto van Veen's composition. ${ }^{29}{ }^{30}$ It was available in print 
following an engraving by a man called Perrett. Giordano had a reputation for both speed and variety in his work. Here the style is High Baroque. It is free and easy and although it gives a sense of space the story feels concise, even dramatic. Again we are presented with the youth, the same array of mythological characters and the milk motif. Why then does Giordano choose the title "Allegory of Syphilis"? Where is the allusion to the disease? Bottom left is a prominent figure, absent from the van Veen picture-a poorly clad, barefoot, young man with a water bottle. When viewed in detail (fig 24) we readily see that he has alopecia and crusted papules on his scalp. And the bridge of his nose has collapsed. Could the long bone in his mouth allude to the bone pains so prominent in the early epidemic years of the morbus gallicus? The archeologist Walters of Monaco was the first to recognise this figure as Syphilus who featured in Fracastorius's poem "Syphilis sive morbus gallicus" (1536) and who gave his name to the new disease. ${ }^{29}$

Giordano's title and intention are thus made clear to us. His comment, although allegorical, is explicit, whereas van Veen's, although the same, is by subtle implication.

Confirmation of van Veen's intent, if such be

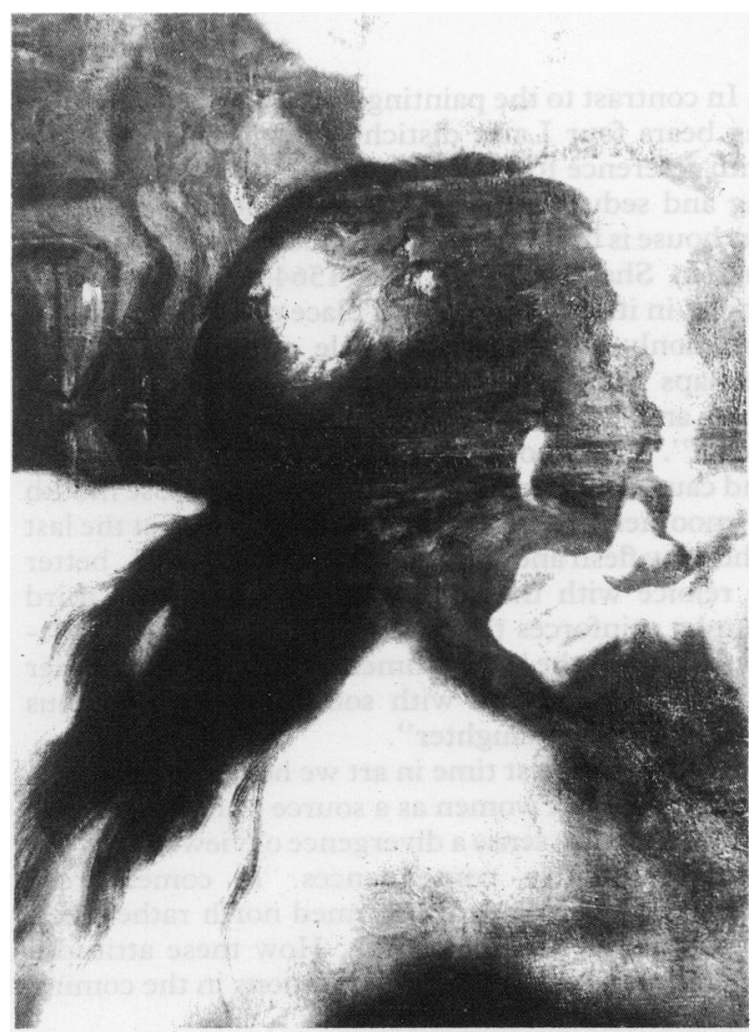

Fig 24 Detail of Fig 23. Courtesy Städelsches Kuntinstitut, Frankfurt. needed, comes from another 16th century work (fig $25)$. In the latter half of the 16 th century, under the influences of the Reformation and prosperity, religious, mythological and allegorical subjects were falling out of favour in northern Europe. Nowhere were the changes more marked than in Holland. The sober pride of that country's merchants called for realism in art. The demand was for everyday scenes, both household and outdoor, together with portraits and all of modest size. Such paintings provided satisfactory decoration for the small but comfortable houses of an increasingly prosperous, Protestant, work-ethic orientated, Dutch community. Thus developed what is called genre painting, in which the more straightforward, even homespun, is used in representations. We recognise in them everyday life and surroundings. Thus the characters in fig 25 are in contemporary dress and northern European countryside dominates the background. Note, for example, the late Gothic chateau with stepped gables, still extant in Holland and Edinburgh.

The painting illustrated is from a museum in Potsdam, East Germany. It was painted in Venice by an unknown artist around 1599 from an engraving (by a Johan Sadeler) itself based on an original work by one Christopher Schwartz. The original painting has not ever been located, but clearly its origin is Netherlandish. It may even have been known to van Veen. The story is readily recognisable. Again we find the contaminating Venus lactans, this time in stone. Note how the flow runs through the trough to form a stream which itself is contaminated by the dog. Our indiscreet youth, called in William van Wyck's translation of Fracastoro's poem, "the sinister shepherd" is drinking from the twice-tainted stream. Wine, food, music and a horn-headed but otherwise alluring damsel suggest seduction. The dignified scholar makes a warning gesture and with his slightly bowed head has an air of admonition. Panofsky ${ }^{18}$ believes he is Fracastorius and sees what he claims is an authentic likeness. He refers to a woodcut, a bronze medallion and a medal, all corresponding in terms of physiognomy with the painting. A personal review of all four, placed alongside each other, leaves me unimpressed but of course this does not preclude an acceptance of the symbolism of the central figure in the genre painting. Acceptable too is the view that the second youth, older and both better dressed and equipped, is Ileus, named as Syphilus's companion in the second book of Fracastorius's poem. Although ambiguities may be read into the picture the title given to it makes no attempt to disguise the original painter's intention. It is simply, if significantly, called "Warning against Veneral Disease". The sage and the companion warn of temptation but it is the symbolic, and symbolically confirmed, representation of contamination which specifically (sic) warns of syphilis. 


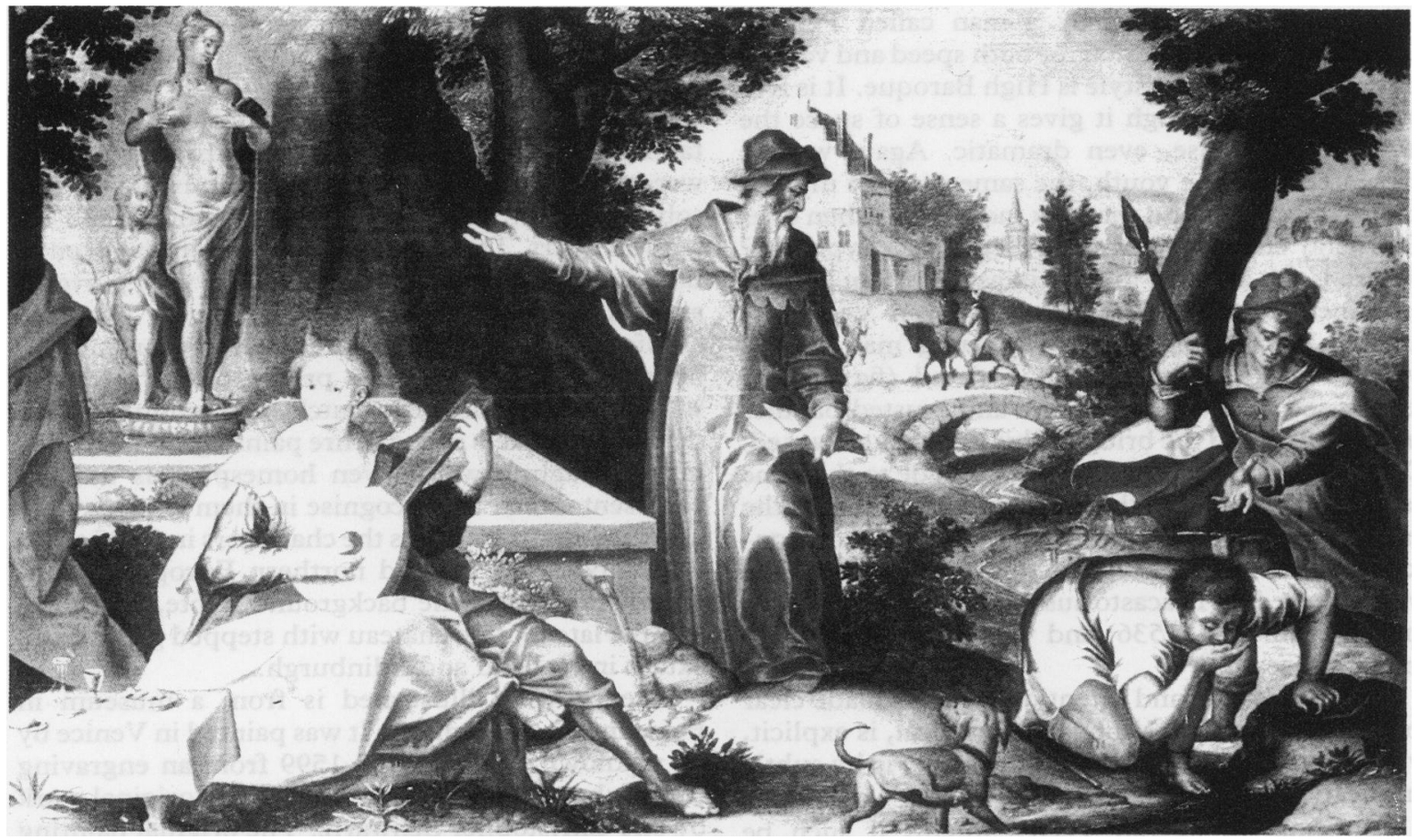

Fig 25 Johan Sadeler after Christopher Schwartz. Warning against Syphilis. Vienna, 1590. Housed at Bilder Galerie, Potsdam. Courtesy Staatliche Schlosser und Garten, Potsdam.

A NDRIAF ALCIATI

Nupid cortagiofo.

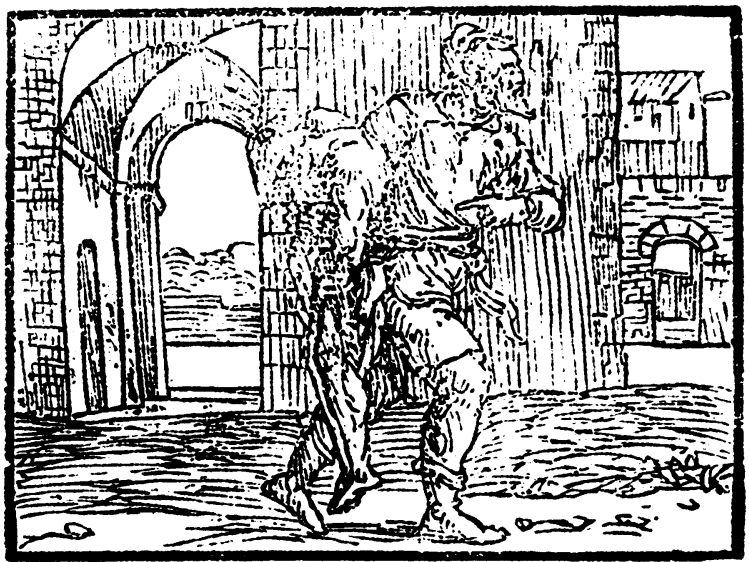

Dü meliora pïs, Mezenti . cur age fic me Compellas ? emptus qudd tibi dote gener,

Gallica quem feabies, dira or mentsgrs perurit . Hoc eft quidnam aliud, dic mibi faue paser,

Corpors corporibus quam iungere mortua uiuis, Effersíg; Etrufci fasta noware ducis ?

Fig 26 Andrea Alciati. Mupta contagioso. Reproduced from Green's Book of Emblems (emblem No 212), London. 1872.
In contrast to the painting itself, Sadeler's engraving bears four Latin distichs or couplets. The first with reference to Proverbs warns against the flattering and seductive woman with an absent husband; her house is the way to hell. It should not be forgotten that in Shakespeare's time (1564-1616) the word "hell" in its sense of being a place of wickedness was commonly used for the female genitals. The bard perhaps has this in mind when he has Hamlet say "... and hell itself breaths out contagion to this world". The second couplet also refers to Proverbs and cautions discretion "with a woman whose mouth is smoother than oil" . . . "You may mourn at the last when thy flesh and thy body are consumed . . . better to rejoice with the wife of thy youth". The third couplet reinforces this last aspect. It counsels satisfaction with "the blandishments of a legal wife rather than risk connection with someone's promiscuous and "shameless daughter".

Here for the first time in art we have a contentious statement about women as a source of infection. For the first time we sense a divergence of views about sex and its possible consequences. It comes from Europe's Anglo-Saxon Reformed north rather than the Latin and Catholic south. How these attitudes develop must await artists' revelations in the coming centuries.

Before we leave the 16th century one example from a minor art form is found to be of social significance. 
From 1546 to the end of the century, Andrea Alciati published several editions of his collection of "Emblemata". These were small woodcuts accompanied by a few lines of poetry. Alciati commended them for spare-time reading and said the printed woodcuts had "a bagetelle quality". Later, his 19th century editor, Green, called the emblems "trifles to amuse". ${ }^{31}$ One emblem called "Nupta contagiosa" (fig 26) is believed to have been contributed by Alciati himself. I am indebted to $\mathrm{Mr}$ Symons of the Wellcome Institute for the History of Medicine (circa 1968) for a translation of the legend. It reads, "The Gods give their benefits to the pious Mezentius, Why do you reproach me? Because with a dowry you have bought yourself a son-in-law who is consumed by the French itch and a terrible eruption. Tell me cruel father, how is this different from marrying the living to the dead and repeating the savage deeds of the Etruscan King?"

Alciati is reminding us of the cruel Etruscan king, Mezentius, who put his subjects to death by tying a living man to a dead one and who bought his troublesome daughter a husband-a dead one. ${ }^{32}$ Marriage to a syphilitic man, the emblem suggests, is no better a fate. "A trifle to amuse", indeed. Incidentally, in Green's Victorian edition (1870) of Alciati's Emblemata the "Nupta contagioso" is passed over without comment. It was a time when such wicked words as "syphilis" and even "venereal disease" could not be used in public.

But what about the dowry and the daughter aspect? It will be the eighteenth century before we again see men bargaining over a daughter and learn how the man she is "sold" to becomes a syphilitic with equally dire consequences.

Address for reprints: 9 Cortworth Rd, Sheffield S11 9LN, UK

15 Plumb JH. The Renaissance. London: Collins, 1961:122.

16 Catalogue to Exhibition at the Louvre 'Homage to Leonardo da Vinci,' 1952.

17 Tabori P. Pictorial History of Love. London: Spring Books, 1966:191-2.

18 Panofsky E. Homage to Fracastoro in a German-Flemish Composition of about 1590. Netherland Yearbook for the History of Art, 1961;12:1-33.

19 Waltman K. Holbein und seine Zeichmurgen. Leipzig, 1879;2:149.

20 Oppenheimer H. Ulrich van Hutten Ueber de Heilkraft des Guaiacum und die Franzosenseuche (De guaiai medecina et morbo Gallico). Berlin: Hirschwald, 1902 (frontispiece).

21 Murray P, Murray L. A Dictionary of Art and Artists (Revised). Hardmonsworth: Penguin Books, 1848.

22 Pusey WA. The History and Epidemiology of Syphilis. Springfield: Thomas, 1933:35.

23 Jeanselme E. Histoire de la Syphilis. Extrait du Traité de la Syphilis. Paris: Doin, 1931;110 \& 197.

24 Jeanselme E. La Cure de la Syphilis au XVI' Siècle. Aesculape, 1925;15:50 \& 89.

25 Levey M. A Room-to-room Guide to the National Gallery, London. The National Gallery, 1964:17.

26 McCorquodale C. Bronzino. London: Jupiter Books, 1981.

27 Williamson GC. Bryan Dictionary of Painters and Engravers. London: Bekk, 1919;2:236.

28 Pickering JG. (personal communication) 1985.

29 Swarzenski G. Un guadro di Luca Giordano in Francoforte sul Meno. Bolletino d'Arte, NS II, 1922-23, 17-21.

30 Ferrari O, Scavizzi G."Luca Giordano". Catalogo delle opere bibliogratia indici analitici, Edizioni scientifiche Italiane (3 Vols) $p 58$ and fig 101, 1966.

31 Green H, ed. Andreae Alicati: Embelmatum fontes quatuor. Manchester and London: Holbein Society, 1870.

32 Virgil. Aeneid viii, 485-8.

Accepted for publication 10 October 1989. 